\title{
key influencing factors and adjustment countermeasures of recovery in heavy oil reservoir of water flooding
}

\author{
Qingting Wei ${ }^{1}$, Guinan Zhen ${ }^{1}$, Weilong Wang ${ }^{1}$, Jiamin Qin ${ }^{1}$, Hongcheng Luo ${ }^{1}$, Xuejie Zhao ${ }^{1}$, Rui Xue ${ }^{2, *}$, \\ Xinbo $\mathrm{Wu}^{2}$ \\ ${ }^{1}$ Xinjiang Oilfield Co., LTD jiqing operating Area, Karamay 834000, Xinjiang, China \\ ${ }^{2}$ E\&D Research Institute of DQ Oilfield, Daqing 163542, Heilongjiang, China.
}

\begin{abstract}
The recovery ratio is an important indicator to evaluate the effectiveness and performance of oilfield development. In order to clarify the key factors of oilfield recovery ratio in the stage of super-high water cut, 9 dynamic indicators of 12 blocks are analyzed in heavy oil reservoir of eastern China in application of reservoir engineering principles and statistical analysis methods. The results show that the four key factors of recovery are the well density, the ratio of producing wells and injecting wells, net cumulative injecting rate and the bottom hole flow pressure, and the weight of each indicator is quantified. In the horizontal contrast, comprehensive forecasting target recovery is compared with the current recovery by the dynamic method to determine according to typical block BXD. Four of important factors are discussed for the previous trend and the countermeasures of according adjustment are put forward. The proposed method and the results have a certain reference value of the theoretical research and practical application in the stage of super-high water cut oil-field.
\end{abstract}

Key words: Super-high water cut stage; Recovery ratio; Influencing factors; Correlation analysis; Grey relational analysis

\section{The introduction}

Most of the heavy oil fields in China have entered or are about to enter the ultra-high water cut development stage, so it is urgent to analyze the key factors affecting the recovery efficiency in the ultra-high water cut stage, so as to provide the basis for the adjustment and decision of the next development of the oilfield.There are many factors affecting recovery, and there are many scholars[1-7]The influence factors of recovery efficiency are discussed in depth from geological conditions, development methods and so on.In the following, based on the example of 12 blocks in the ultra-high water cut period of sandstone heavy oil reservoirs in western China, the key influencing factors of oilfield recovery are analyzed by combining objective analysis with subjective analysis.

\section{Statistical and quantitative discussion of key factors of influencing recovery}

For a lot of factors of influencing the oilfield recovery, they often influence each other. In the analysis of the inluencing recovery factors, several representative indicators could be first selected commonly, focuses on subjective analysis - that is, on the principle of reservoir engineering and practical experience in primarily in the judgment, as the important reference in mathematical methods of quantitative results, at the same time to determine the various factors affecting the synthesis weights of factors influencing the sorting, then appraise the typical block, and the next step adjustment countermeasures are presented.

Taking 9 development indicators related to recovery of 12 blocks in the ultra-high water cut stage (between $90 \%$ and $95 \%$ ) as cases (Tab. 1), the calculated correlation coefficient between two indicators of each block ecovery are shown in Tab. 2.

\footnotetext{
Corresponding author: xuerui@cnpc.com.cn
} 
Tab. 1. Indicators of influencing recovery of 12 blocks

\begin{tabular}{|c|c|c|c|c|c|c|c|c|c|c|c|c|}
\hline $\begin{array}{l}\text { Indic } \\
\text { ator } \backslash \\
\text { block }\end{array}$ & $\begin{array}{l}\mathrm{Bl} \\
\mathrm{oc} \\
\mathrm{k} \\
1\end{array}$ & $\begin{array}{l}\mathrm{Bl} \\
\mathrm{oc} \\
\mathrm{k} \\
2\end{array}$ & $\begin{array}{c}\mathrm{Bl} \\
\mathrm{oc} \\
\mathrm{k} \\
3\end{array}$ & $\begin{array}{l}\mathrm{Bl} \\
\mathrm{oc} \\
\mathrm{k} \\
4\end{array}$ & $\begin{array}{c}\mathrm{Bl} \\
\mathrm{oc} \\
\mathrm{k} \\
5\end{array}$ & $\begin{array}{l}\mathrm{Bl} \\
\mathrm{oc} \\
\mathrm{k} \\
6\end{array}$ & $\begin{array}{l}\mathrm{Bl} \\
\mathrm{oc} \\
\mathrm{k} \\
7\end{array}$ & $\begin{array}{l}\mathrm{Bl} \\
\text { oc } \\
\mathrm{k} \\
8\end{array}$ & $\begin{array}{l}\mathrm{Bl} \\
\mathrm{oc} \\
\mathrm{k} \\
9\end{array}$ & $\begin{array}{c}\mathrm{Bl} \\
\mathrm{oc} \\
\mathrm{k} \\
10\end{array}$ & $\begin{array}{c}\mathrm{Bl} \\
\mathrm{oc} \\
\mathrm{k} \\
11\end{array}$ & $\begin{array}{c}\mathrm{Bl} \\
\mathrm{oc} \\
\mathrm{k} \\
12\end{array}$ \\
\hline $\begin{array}{l}\text { recov } \\
\text { ery }\end{array}$ & $\begin{array}{l}43 \\
.1 \\
2\end{array}$ & $\begin{array}{l}40 \\
.5 \\
6\end{array}$ & $\begin{array}{l}40 \\
.6 \\
9\end{array}$ & $\begin{array}{c}38 \\
.9 \\
6\end{array}$ & $\begin{array}{c}41 \\
.9 \\
0\end{array}$ & $\begin{array}{l}37 \\
.1 \\
6\end{array}$ & $\begin{array}{l}36 \\
.8 \\
3\end{array}$ & $\begin{array}{l}35 \\
.5 \\
6\end{array}$ & $\begin{array}{l}44 \\
.7 \\
5\end{array}$ & $\begin{array}{l}34 \\
.8 \\
1\end{array}$ & $\begin{array}{l}40 \\
.1 \\
4\end{array}$ & $\begin{array}{l}35 \\
.3 \\
8\end{array}$ \\
\hline $\begin{array}{l}\text { Fluid } \\
\text { produ } \\
\text { ctivit } \\
\text { y } \\
\text { index }\end{array}$ & $\begin{array}{l}13 \\
.0 \\
4\end{array}$ & $\begin{array}{c}5 . \\
86\end{array}$ & $\begin{array}{l}9 . \\
70\end{array}$ & $\begin{array}{l}12 \\
.9 \\
2\end{array}$ & $\begin{array}{l}14 \\
.4 \\
0\end{array}$ & $\begin{array}{c}6 . \\
07\end{array}$ & $\begin{array}{l}8 . \\
16\end{array}$ & $\begin{array}{l}5 . \\
95\end{array}$ & $\begin{array}{l}5 . \\
74\end{array}$ & $\begin{array}{c}6 . \\
12\end{array}$ & $\begin{array}{l}5 . \\
36\end{array}$ & $\begin{array}{l}2 . \\
62\end{array}$ \\
\hline $\begin{array}{c}\text { Oil } \\
\text { well } \\
\text { flow } \\
\text { press } \\
\text { ure } \\
\end{array}$ & $\begin{array}{l}3 . \\
45\end{array}$ & $\begin{array}{l}2 . \\
99\end{array}$ & $\begin{array}{l}3 . \\
41\end{array}$ & $\begin{array}{l}4 . \\
03\end{array}$ & $\begin{array}{l}3 . \\
66\end{array}$ & $\begin{array}{l}4 . \\
48\end{array}$ & $\begin{array}{l}3 . \\
91\end{array}$ & $\begin{array}{l}3 . \\
93\end{array}$ & $\begin{array}{l}3 . \\
01\end{array}$ & $\begin{array}{l}4 . \\
56\end{array}$ & $\begin{array}{l}3 . \\
71\end{array}$ & $\begin{array}{l}3 . \\
72\end{array}$ \\
\hline $\begin{array}{l}\text { The } \\
\text { inten } \\
\text { sity } \\
\text { of oil } \\
\text { recov } \\
\text { ery }\end{array}$ & $\begin{array}{c}0 . \\
15\end{array}$ & $\begin{array}{c}0 . \\
09\end{array}$ & $\begin{array}{l}0 . \\
08\end{array}$ & $\begin{array}{c}0 . \\
11\end{array}$ & $\begin{array}{c}0 . \\
13\end{array}$ & $\begin{array}{c}0 . \\
10\end{array}$ & $\begin{array}{l}0 . \\
18\end{array}$ & $\begin{array}{l}0 . \\
11\end{array}$ & $\begin{array}{l}0 . \\
09\end{array}$ & $\begin{array}{c}0 . \\
06\end{array}$ & $\begin{array}{l}0 . \\
12\end{array}$ & $\begin{array}{l}0 . \\
16\end{array}$ \\
\hline $\begin{array}{c}\text { Reco } \\
\text { very } \\
\text { degre } \\
\text { e }\end{array}$ & $\begin{array}{c}39 \\
.1 \\
1\end{array}$ & $\begin{array}{c}32 \\
.0 \\
4\end{array}$ & $\begin{array}{r}29 \\
.2 \\
2\end{array}$ & $\begin{array}{c}33 \\
.6 \\
1\end{array}$ & $\begin{array}{r}33 \\
.5 \\
7\end{array}$ & $\begin{array}{r}25 \\
.5 \\
2\end{array}$ & $\begin{array}{l}29 \\
.6 \\
9\end{array}$ & $\begin{array}{c}22 \\
.3 \\
2\end{array}$ & $\begin{array}{c}32 \\
.3 \\
3\end{array}$ & $\begin{array}{c}25 \\
.1 \\
1\end{array}$ & $\begin{array}{l}30 \\
.1 \\
5\end{array}$ & $\begin{array}{c}22 \\
.6 \\
5\end{array}$ \\
\hline $\begin{array}{l}\text { Oil- } \\
\text { well } \\
\text { ratio } \\
\end{array}$ & $\begin{array}{l}1 . \\
27\end{array}$ & $\begin{array}{c}2 . \\
10\end{array}$ & $\begin{array}{l}1 . \\
29\end{array}$ & $\begin{array}{c}1 . \\
58\end{array}$ & $\begin{array}{l}1 . \\
02\end{array}$ & $\begin{array}{l}1 . \\
88\end{array}$ & $\begin{array}{l}1 . \\
67\end{array}$ & $\begin{array}{c}1 . \\
89\end{array}$ & $\begin{array}{l}1 . \\
56\end{array}$ & $\begin{array}{c}2 . \\
03\end{array}$ & $\begin{array}{l}1 . \\
08\end{array}$ & $\begin{array}{l}1 . \\
81\end{array}$ \\
\hline $\begin{array}{c}\text { Cum } \\
\text { ulativ } \\
\mathrm{e} \\
\text { water } \\
\text { stora } \\
\text { ge } \\
\text { rate } \\
\end{array}$ & $\begin{array}{c}37 \\
.9 \\
0\end{array}$ & $\begin{array}{l}39 \\
.5 \\
2\end{array}$ & $\begin{array}{l}41 \\
.3 \\
4\end{array}$ & $\begin{array}{c}40 \\
.4 \\
1\end{array}$ & $\begin{array}{l}47 \\
.5 \\
1\end{array}$ & $\begin{array}{c}39 \\
.2 \\
8\end{array}$ & $\begin{array}{c}42 \\
.4 \\
9\end{array}$ & $\begin{array}{l}40 \\
.1 \\
9\end{array}$ & $\begin{array}{l}42 \\
.6 \\
0\end{array}$ & $\begin{array}{c}40 \\
.9 \\
9\end{array}$ & $\begin{array}{c}38 \\
.4 \\
6\end{array}$ & $\begin{array}{l}35 \\
.1 \\
2\end{array}$ \\
\hline $\begin{array}{c}\text { Dyna } \\
\text { mic } \\
\text { press } \\
\text { ure } \\
\text { differ } \\
\text { ence } \\
\text { betw } \\
\text { een } \\
\text { inject } \\
\text { ion- } \\
\text { produ } \\
\text { ction } \\
\text { Wells }\end{array}$ & $\begin{array}{c}13 \\
.2 \\
5\end{array}$ & $\begin{array}{c}17 \\
.9 \\
4\end{array}$ & $\begin{array}{l}15 \\
.0 \\
0\end{array}$ & $\begin{array}{c}16 \\
.0 \\
1\end{array}$ & $\begin{array}{c}13 \\
.6 \\
0\end{array}$ & $\begin{array}{l}18 \\
.0 \\
4\end{array}$ & $\begin{array}{l}18 \\
.6 \\
7\end{array}$ & $\begin{array}{c}15 \\
.9 \\
8\end{array}$ & $\begin{array}{l}17 \\
.4 \\
2\end{array}$ & $\begin{array}{c}18 \\
.5 \\
8\end{array}$ & $\begin{array}{l}17 \\
.7 \\
3\end{array}$ & $\begin{array}{l}18 \\
.6 \\
2\end{array}$ \\
\hline $\begin{array}{c}\text { Inject } \\
\text { ion } \\
\text { poros } \\
\text { ity } \\
\text { multi } \\
\text { ple }\end{array}$ & $\begin{array}{l}1 . \\
24\end{array}$ & $\begin{array}{l}0 . \\
73\end{array}$ & $\begin{array}{l}1 . \\
34\end{array}$ & $\begin{array}{l}1 . \\
02\end{array}$ & $\begin{array}{c}0 . \\
99\end{array}$ & $\begin{array}{l}0 . \\
82\end{array}$ & $\begin{array}{l}0 . \\
69\end{array}$ & $\begin{array}{l}0 . \\
59\end{array}$ & $\begin{array}{l}0 . \\
70\end{array}$ & $\begin{array}{l}0 . \\
69\end{array}$ & $\begin{array}{l}0 . \\
79\end{array}$ & $\begin{array}{l}0 . \\
75\end{array}$ \\
\hline $\begin{array}{c}\text { Well } \\
\text { spaci } \\
\text { ng } \\
\text { densi } \\
\text { ty }\end{array}$ & $\begin{array}{c}48 \\
.0 \\
3\end{array}$ & $\begin{array}{l}50 \\
.9 \\
0\end{array}$ & $\begin{array}{l}49 \\
.7 \\
5\end{array}$ & $\begin{array}{c}40 \\
.0 \\
7\end{array}$ & $\begin{array}{c}55 \\
.9 \\
3\end{array}$ & $\begin{array}{c}32 \\
.9 \\
7\end{array}$ & $\begin{array}{l}19 \\
.2 \\
4\end{array}$ & $\begin{array}{c}20 \\
.8 \\
2\end{array}$ & $\begin{array}{r}37 \\
.9 \\
7\end{array}$ & $\begin{array}{c}29 \\
.1 \\
4\end{array}$ & $\begin{array}{l}34 \\
.1 \\
8\end{array}$ & $\begin{array}{l}18 \\
.8 \\
2\end{array}$ \\
\hline
\end{tabular}

Tab. 2. Correlation coefficient between two factors of influencing recovery

\begin{tabular}{|c|c|c|c|c|}
\hline $\begin{array}{c}\text { The serial } \\
\text { number }\end{array}$ & indicators & correlation & indicators & $\begin{array}{c}\text { The } \\
\text { correlation }\end{array}$ \\
\hline 1 & Recovery degree & 0.7486 & Recovery degree & 0.8334 \\
\hline 2 & $\begin{array}{c}\text { Net injection } \\
\text { percentage }\end{array}$ & 0.7301 & $\begin{array}{c}\text { Well spacing } \\
\text { density }\end{array}$ & 0.7542 \\
\hline 3 & $\begin{array}{c}\text { Well-bottom } \\
\text { flowing pressure }\end{array}$ & 0.6876 & $\begin{array}{c}\text { Injection porosity } \\
\text { multiple }\end{array}$ & 0.4791 \\
\hline 4 & $\begin{array}{c}\text { Well spacing } \\
\text { density }\end{array}$ & 0.6688 & $\begin{array}{c}\text { Fluid } \\
\text { productivity } \\
\text { index, }\end{array}$ & 0.4578 \\
\hline 5 & $\begin{array}{c}\text { The intensity of } \\
\text { oil recovery }\end{array}$ & 0.6792 & $\begin{array}{c}\text { Cumulative water } \\
\text { storage rate }\end{array}$ & 0.3310 \\
\hline 6 & $\begin{array}{c}\text { Injection porosity } \\
\text { multiple }\end{array}$ & 0.6539 & $\begin{array}{c}\text { The intensity of } \\
\text { oil recovery }\end{array}$ & 0.1139 \\
\hline 8 & $\begin{array}{c}\text { Fluid } \\
\text { productivity } \\
\text { index, } \\
\text { pressure } \\
\text { difference } \\
\text { between } \\
\text { injection- } \\
\text { production Wells }\end{array}$ & 0.5498 \\
\hline 9 & $\begin{array}{c}\text { Inj. \& Pro. Well } \\
\text { ratio }\end{array}$ & 0.5744 & Oil-well ratio & 0.6018 \\
\hline & $\begin{array}{c}\text { Dynamic } \\
\text { pressure } \\
\text { difference } \\
\text { between } \\
\text { injection- } \\
\text { production Wells }\end{array}$ & 0.5719 & Oil well flow \\
pressure & 0.7488 \\
\hline
\end{tabular}

After removing the factors affecting the degree of production, the top four indexes calculated by the two methods are the cumulative net injection percentage, well spacing density, well-bottom flowing pressure and Inj. \&
Pro. Well ratio. The relationship between the recovery degree and recovery is self-evident for the oil field in the ultra-high water cut stage. The greater the recovery degree, the greater the recovery. The well-bottom flowing pressure and Inj. \& Pro. Well ratio is not positively correlated with the recovery. In other words,, the smaller the well-bottom flowing pressure and Inj. \& Pro. Well ratio are, the higher the recovery will be, which is consistent with theoretical understanding and practical knowing on site.The effects of well pattern density and cumulative water retention rate on recovery in the ultrahigh water cut period will be discussed later.Based on the comprehensive analysis and judgment of reservoir engineering principle and field practice, the key factors of recovery in the extra-high water cut period include well pattern density, Inj. \& Pro. Well ratio, cumulative net injection percentage and well-bottom flowing pressure. The results of calculating the weight of the several indicators, as shown in Tab. 3 :

Tab. 3. Weight of key factors of influencing recovery

\begin{tabular}{|c|c|c|c|c|}
\hline $\begin{array}{c}\text { category } 1 \\
\text { index }\end{array}$ & $\begin{array}{c}\text { well- } \\
\text { bottom } \\
\text { flowing } \\
\text { pressure }\end{array}$ & $\begin{array}{c}\text { Inj. \& } \\
\text { Pro. } \\
\text { Well } \\
\text { ratio }\end{array}$ & $\begin{array}{c}\text { net injection } \\
\text { percentage }\end{array}$ & $\begin{array}{c}\text { Well } \\
\text { pattern } \\
\text { density }\end{array}$ \\
\hline $\begin{array}{c}\text { Related } \\
\text { rights }\end{array}$ & 0.2662 & 0.2632 & 0.2792 & 0.2004 \\
\hline $\begin{array}{c}\text { Right of } \\
\text { variation }\end{array}$ & 0.1670 & 0.2895 & 0.0948 & 0.4487 \\
\hline $\begin{array}{c}\text { Level of } \\
\text { power }\end{array}$ & 0.2461 & 0.3160 & 0.1917 & 0.2461 \\
\hline $\begin{array}{c}\text { Integrated } \\
\text { power }\end{array}$ & 0.2284 & 0.3005 & 0.1788 & 0.2922 \\
\hline
\end{tabular}

According to the statistical results, for the oil field in the ultra-high water cut stage, the most important factor affecting the recovery is the oil-well number ratio, followed by well pattern density and well flow pressure, and the net injection percentage.

On the basis of determining the key factors affecting the recovery efficiency, the following takes BXD block, a typical block of ultra-high water-cut heavy oilfield, as a case for in-depth analysis.

\section{BXD recovery efficiency evaluation of typical blocks}

(1) discussion of influencing factors

1) Well pattern density

The relationship model between well pattern density and recovery efficiency was proposed by serkachev, a scholar of the former Soviet Union, in the late 1960s according to the statistical results of oilfield data[10]With the increase of well pattern density, the recovery is also increasing. The expression is as follows:

$$
E_{R}=E_{D} \cdot e^{-a / s}
$$

Type:

$E_{R^{--}}$Recovery factor, $\% ; E_{D^{--}}$Oil flooding efficiency, $\%$; $\mathrm{S}$-- Well pattern density, well $/ \mathrm{km}^{2}$; a -- Well pattern density index. 
By means of the data of coring Wells since 2012, the flooding efficiency of BXD block is $38 \%$, and the calculated well pattern index is 6.13 . The variation trend of the calculated recovery factor with well pattern density is shown in Fig. 1.It is obvious that the recovery rate increases less and less as the well pattern density increases, which is a key factor for the present recovery to be lower than the expected recovery, and the actual recovery will be lower because the well pattern density is much lower than the surface well pattern density because the well pattern density is much lower underground.

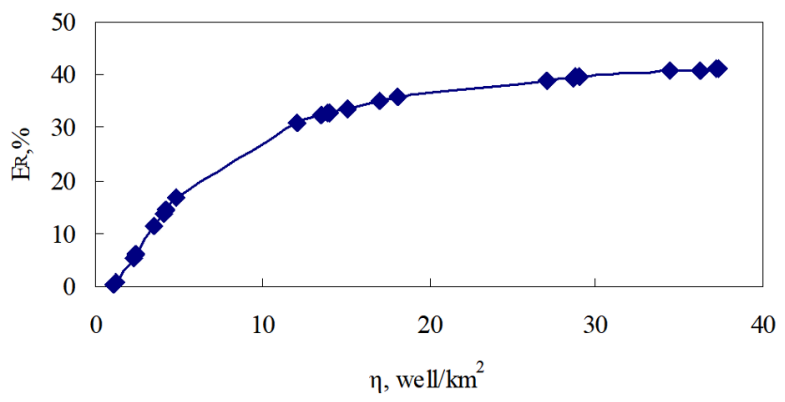

Fig. 1 Recovery curve of BXD block with well pattern density

The variation trend of EOR of BXD block in unit well density under different water cut conditions since the extta-high water cut stage, as shown in Fig. 2.

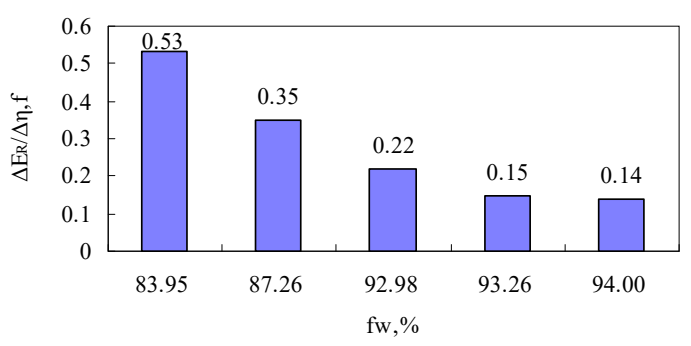

Fig. 2 Enhanced recovery per unit pattern density under different water cut conditions

In the high water cut stage, with the increase of well pattern density, the value of enhanced oil recovery decreases promptly. If the higher recovery is not got before the extra-high water cut stage, even if the well pattern density increases substantially, the increasement of oilfield recovery will decrease remarkably. The variation trend of $\mathrm{BXD}$ is that the water cut rises significantly in the initial development stage, which cannot guarantee high recovery efficiency. As a result, the recovery efficiency does not increase significantly even after multiple well pattern infusing and injectable system adjustment. However, infilling adjustment is inevitably a key way of EOR.

2) Inj. \& Pro. Well ratio

Reasonable oil-well ratio is a key aspect to guarantee the balancing between injection and production and expand sweep volume for the oil field in ultra-high water-cut stage. It has been verified that injecting water theory and Inj. \& Pro. Well ratio have great influence on water injection swept volume and water drive recovery efficiency in waterflooding sandstone oil fields. When well density and water injection multiple invary, with the relative reduction of Inj. \& Pro. Well ratio, the number of effective directions of working production well increases, the controlling degree of water dirving increases, and the water injection conformance correspondingly increases. On the contrary, when the Inj. \& Pro. well ratio decreases, it decreases and the multi-direction efficiency is lower and lower. Therefor, the sweeping conformance of water injection would decrease correspondingly. In oilfield injection-production pattern adjustment, has a mass of theoretical research and field practice shows that under the condition of the well spacing density rekeys constant, by varying the ratio of oil and water wells numbers to adjust flowing direction, to better the exploiting effect, increasing water flooding recoverable reserves and improve water drive recovery is the purpose of practical (Fig. 3).

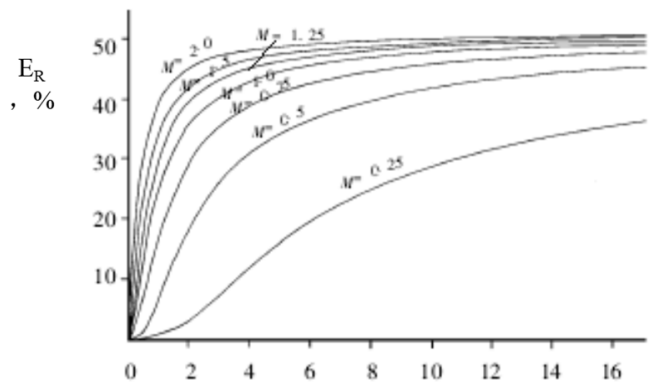

Fig. 3 Relationship curve of well density, Inj. \& Pro. well num. ratio and recovery in Shuanghe Oilfield

(From Yang Fengbo, Effect of Inject-production Well Ratio on Water-Flooding Recovery, Xinjiang Petroleum Geology, 1998)

In the case of a constant well pattern density, the lower the Inj. \& Pro. Well ratio is, the less the recovery will be. Nevertheless, with the increasing of well numbers, the impact of Inj. \& Pro. Well num. ratio on recovery will become smaller and smaller, and the increase of recovery will become smaller.

The variation curve of oil-well ratio in BXD block is shown in Fig.4.Another factor contributing to lower recovery is the gradual adjustment of the oil-well ratio from a high of 2.37 in the 1980 s to 1.99 in the 1990 s and to 1.53 in the $2000 \mathrm{~s}$.

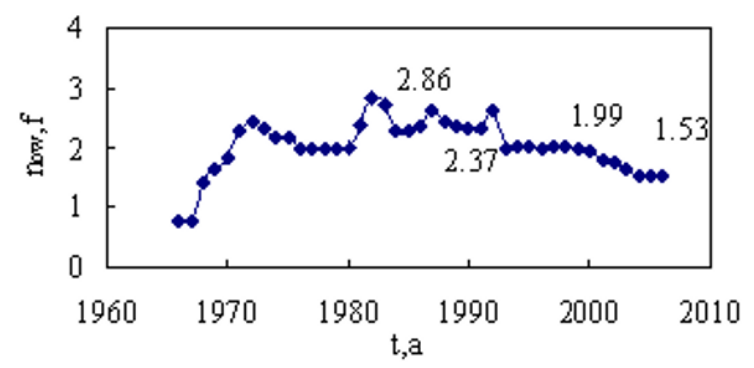

Fig. 4 The changing curve of Inj. \& Pro. Well ratio about BXD block

3) net injection percentage 
For single-layer oil fields, the recovery factor is the product of the key oil displacement efficiency and sweep volume (Formula 2). The sweep volume coefficient of injected water refers to the difference between the cumulative injection water and cumulative water production divided by the geological reserves, that is, the average oil displacement efficiency of the water-flooded part of the oil layer, also called sweep volume coefficient (Formula 3).

$$
\begin{array}{r}
E_{R}=E_{D} \mathrm{~g} E_{V} \\
E_{v}=\frac{W_{i}-W_{p}}{N}
\end{array}
$$

According to the definition of net injection percence :

$$
E_{s}=\frac{W_{i}-W_{p}}{W_{i}}
$$

As for the total injection multiples:

$$
\gamma_{\phi}=\frac{W_{i}}{N}
$$

To obtain:

$$
E_{v}=E_{s} \mathrm{~g}_{\phi}
$$

in a certain range, total injection pore volume ratio is not a great change, thus affecting coefficient is keyly accumulated water rate, conformance with increase with the increase of the accumulated water rate, especially for water drive oilfield, oil displacement efficiency increased under the condition of limited, the key direction of enhanced recovery is to increase the swept volume coefficient.As can be seen from Fig. 5, when the injected pore multiple is certain, the recovery factor increases with the increase of cumulative water storage rate and the increase of conformance. The theoretical relation between cumulative water storage rate and water content is derived $^{[11]}$. As can be seen from Figure 6, the actual cumulative water storage rate is nearly 6.8 percentage points lower than the theoretical cumulative water storage rate, which is another reason for the low recovery.

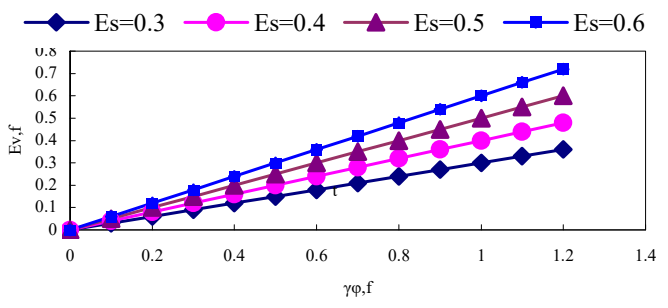

Fig. 5 Variation curves of injection multiple and conformance under different cumulative water storage rates

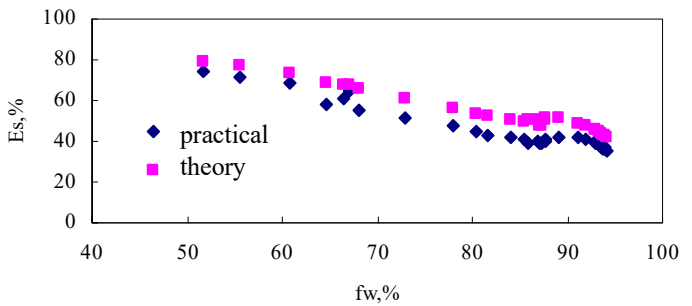

Fig. 6 Variation curve of BD theory and actual water storage rate with water content

4) well-bottom flowing pressure

According to the previous understandings[12], production and recovery theory, there would be a turning corner between well-bottom flowing pressure and recovery, when the well-bottom flowing pressure is about 2.1 3.2MPa, the recovery is the largest.However, the current flow pressure of the block is $3.7 \mathrm{mpa}$, which exceeds the value of $0.4-1.6 \mathrm{mpa}$ to maximize the recovery efficiency, which has a approximate influence on the recovery.

In conclusion, one of small recovery of the reasons in BXD block: firstly, the high reservoir heterogeneity (permeability variation coefficient of BXD is 0.5945) caused interally; on the other hand, external factors caused to incorrectly enhanced recovery measurements, it leaded to "the three major contradictions" in particular, determining to encrypt and injection \& production system adjustment and keep high flowing pressure. In the early stage of oilfield development, the water cut rapidly rising, which leading to infilling in the middle and late stage. Moreover, the injection-production system adjustment has failed to EOR of BXD, and net injection percentage has been small. To enhance oil recovery of BXD is difficult because of aboving reasons.

(2) development countermeasure

Based on the analysis of the above four aspects, the specific development countermeasures are put forward for BXD.

Firstly, the economic and maxmum well density of BXD at $50 \$ / \mathrm{bbl}$ calculated is $60 \mathrm{well} / \mathrm{km}^{2}$ or so by using the improved Xie's formula, which current well density is 38 well $/ \mathrm{km}^{2}$, enhanced oil recovery by $0.8-1$ percentage points through infilling;

Secondly, the recovery of BXD would be improved by $0.1-0.2$ percentage points by reducing the production well numbers, and the optimal Inj. \& Pro. Well ratio is 1.18 under present conditions.

Thirdly, in terms of improving the net injection percentage, the underground water storage rate can be improved by $0.1-0.2$ percentage points by carrying out deep profile control to improve the water absorption profile.

Fourthly, with well-bottom flowing pressure reducing, the fluid of low water cut layers could be producted, and low water cut wells be stimulated to improve the liquid production.

These measurements can validly reduce the declining rate of the oilfield and add oil recovery to 0.3 to 1.6 percent. 


\section{Conclusion}

Through the above research, the following conclusions are drawn:

(1) the paper for the first time put forward from two aspects of straight line and curve of related using the method of correlation coefficient and grey correlation analysis method to analysis the key influence factors of determining recovery rate, the results show that the primary factors influencing the determining oil field recovery is Inj. \& Pro. Well ratio, followed by well spacing density and well-bottom flowing pressure, the next is net injection percentage;

(2) The method of weight determination by complex correlation coefficient method and variation coefficient method is analyzed, and the integrated weight calculating method is put forward, which offers theoretical support for the oilfields development of extra-high water cut satage;

(3) The mathematical relation between net injection percentage and sweep volume coefficient is established. It is pointed out that water storage rate can not only be used to evaluate the utilization efficiency of injected water, but also closely related to recovery efficiency.

\section{References}

1. Jia Zili, GAO Wenjun, ZHAO Xiaoping, et al. Determination of reasonable well pattern density and injection-production well number ratio in waterflooding oilfield $[\mathrm{J}]$. Xinjiang petroleum geology, 2005,26 (5) : 562-564.

2. Qian Shenhua, Li Yongfu, Yuan Chengzhang. Determination of economic and reasonable well pattern density for oilfield infilling adjustment [J]. Petroleum geology and oilfield development in daqing, 2000,19 (4) : 23-25.

3. Li Zhourong, XUE Zhiguo, Chen Kunlin, et al. Determination method of reasonable well pattern density in later stage of oilfield development [J]. Petroleum geology and recovery efficiency, 2002,9 (3) : 78-80.

4. Guan J A, Cheng Z P. Study on determining parameters of Xie's Formula by Using actual Production Data $[\mathrm{J}]$. Special oil and gas reservoirs, 2003,10 (3) : 57-59.

5. Yang Fengbo. Effect of injection-production ratio on water flooding recovery $[\mathrm{J}]$. Xinjiang petroleum geology, 1998,19 (5) : 410-413.

6. Gao Wenjun, Huang Shibin, Lu Yi. Study on the influence of injection-production well pattern on water flooding recovery $[\mathrm{J}]$. Turpan-hami oil and gas, 2000,5 (2) : 27-30.

7. Peng Changshui, Gao Wenjun, Li Zhengke. Effect of injection-production well pattern on water flooding recovery $[\mathrm{J}]$. Xinjiang petroleum geology, 2000,21 (4) : 315-317.

8. (USA) by R.L. OTT, m. langenecker, translated by zhang zhongzhan.An introduction to statistical methods and data analysis [M].Beijing: Science Press, 2003:35-37.

9. $\mathrm{Hu}$ Bozhong, Editor-in-chief.Study on the application of multi-layer production technology in heterogeneous sandstone oilfield [J].Beijing: Petroleum Industry Press, 2000, 315-317.

10. Song Yong.Adjustment technology of water injection development in Daqing oilfield [M]. Beijing: Petroleum Industry Press, 2005, 119-121.

11. Zhang Jifeng, TIAN Xiaodong, Wang Tianzhi, et al.Theoretical relationship between cumulative water storage rate and water cut in water flooding oilfield [J].Xinjiang petroleum geology, 2006,27 (4) : 466467,477 .

12. Gang Wang. Study on the key influencing factors of oil-flood recovery of oilfield in extra-high water cut period, 2020, vol 514, IOP Conference Series: Earth and Environmental Science 